Institut für Lebensmittelsicherheit und -hygiene der Vetsuisse-Fakultät, Universität Zürich

Direktor: Prof. Dr. Roger Stephan

Arbeit unter wissenschaftlicher Betreuung von

PD Dr. Claudio Zweifel

\title{
Shedding of foodborne pathogens and microbial carcass contamination
} of hunted wild ruminants

\author{
Inaugural-Dissertation \\ zur Erlangung der Doktorwürde der \\ Vetsuisse-Fakultät Universität Zürich \\ vorgelegt von \\ Tobias Obwegeser \\ Tierarzt \\ von Schwerzenbach (ZH), Schweiz
}

genehmigt auf Antrag von

Prof. Dr. Roger Stephan

Zürich, 2012 


\section{CONTENTS}

1. Summary 3

$\begin{array}{lll}2 . & \text { Introduction } & 4\end{array}$

3. Materials and methods 5

3.1. Sampling 5

3.2. Salmonella spp. 5

3.3. Listeria monocytogenes 6

3.4. Escherichia coli harboring stx and eae 6

3.5. Total viable counts and Enterobacteriaceae 6

$\begin{array}{lll}\text { 4. } & \text { Results } & 7\end{array}$

4.1. Salmonella spp. and Listeria monocytogenes 7

4.2. Escherichia coli harboring stx and eae 7

4.3. Total viable counts and Enterobacteriaceae 8

$\begin{array}{lll}5 . & \text { Discussion } & 8\end{array}$

$\begin{array}{lll}\text { 6. } & \text { References } & 11\end{array}$

$\begin{array}{lll}\text { 7. Tables } & 14\end{array}$

$\begin{array}{lll}\text { 8. } & \text { Figures } & 18\end{array}$

9. Acknowledgements 
Shedding of foodborne pathogens and microbial carcass contamination of hunted wild ruminants

Tobias Obwegeser, Roger Stephan, Eveline Hofer, Claudio Zweifel* Institute for Food Safety and Hygiene, Vetsuisse Faculty University of Zurich, Zurich, Switzerland

*Corresponding author: Claudio Zweifel, Institute for Food Safety and Hygiene, Vetsuisse Faculty University of Zurich, Winterthurerstrasse 272, CH-8057 Zurich, Switzerland. Phone: +41 44635 8651, Fax: +41 44635 8908, E-mail: ils@fsafety.uzh.ch

Accepted for publication in Veterinary Microbiology

In fulfillment of the doctoral thesis of Tobias Obwegeser 


\section{Summary}

To assess the shedding of selected bacterial foodborne pathogens, fecal samples from 239 hunted wild red deer, roe deer, chamois, and ibex were examined. All samples tested negative for Salmonella spp. and L. monocytogenes but other Listeria species were occasionally found. Of the 239 fecal samples, $32.6 \%$ tested positive for stx (Shiga toxins), $6.7 \%$ for eae (intimin) and $13.8 \%$ for both stx and eae genes. Amongst the 56 isolated Shiga toxin-producing Escherichia coli (STEC) strains, 44.6\% harbored genes for the Stx 2 group, $30.4 \%$ for the Stx 1 group, and $21.4 \%$ for both Stx 1 and Stx2. Only two of these strains harbored eae. Hence, wild ruminants constitute a reservoir for STEC but further characterization data of the isolated strains are required to assess their actual human pathogenicity. In addition, 328 carcasses from hunted wild red deer, roe deer, and chamois were examined for total viable counts (TVC) and Enterobacteriaceae by swabbing. For the examined species, average total viable counts (4.0-4.2 $\left.\log \mathrm{CFU} \mathrm{\textrm {cm } ^ { - 2 }}\right)$ and average Enterobacteriaceae counts/detection rates $\left(2.3-2.6 \log \mathrm{CFU} \mathrm{cm}{ }^{-2} ; 87.5-\right.$ $90 \%$ ) were at comparable levels. On the other hand, the microbial status of carcasses differed between certain abattoirs by several orders of magnitude. Strict compliance with good hunting and hygiene practices during any step from shooting, through evisceration in the field, to dehiding, cooling, and processing is therefore of central importance to avoid contaminations and to prevent foodborne pathogens carried by the animals from entering the food chain.

Keywords: Hunted wild ruminants; Fecal shedding; Salmonella; Listeria monocytogenes; Shiga toxin-producing Escherichia coli; Carcass contamination 


\section{Introduction}

Game meat is appreciated for its nutritional, physiological, and dietary properties. World game meat production is estimated to be over 1.8 million tons annually (FAO, 2011). In central Europe, annual per capita consumption is about one kilogram (Atanassova et al., 2008; Membré et al., 2011) and the demand for game meat has increased in recent years. Of the game consumed in Switzerland, 20-25\% originates from domestic production, mainly domestic hunts (Proviande, 2010). With regard to wild ruminants hunted in the year 2010, 9’016 red deer, 39'664 roe deer, 13'339 chamois, and 1'074 ibex were shot in Switzerland (BAFU, 2010). In the European Union, wild game and game meat are covered by the food hygiene legislation (Reg. [EC] No 852/2004 and $853 / 2004)$. Hunters selling game to processing companies are considered food business operators with respective responsibilities in view of food safety or traceability (Atanassova et al., 2008).

The microbial conditions of carcasses and meat obtained from hunted animals can vary greatly. Several highly variable factors influence both the initial contamination and the potential subsequent growth of the bacterial flora (Gill, 2007; Paulsen, 2011). These factors include but are not limited to: the health of the animal, the types of microorganisms present, the circumstances in which the animal is killed, the evisceration in the field, the time before cooling, the practice of hanging unskinned carcasses, or the conditions under which carcasses are transported, stored, and processed. Thereby, it must be considered that healthy animals were recognized in recent years as important carriers of bacterial pathogens causing human illness (EFSA/ECDC, 2011). Such zoonotic pathogens from the intestine or the hide might enter the food chain by direct or indirect fecal contamination if good hunting and hygiene practices are not warranted. Because recent data from healthy wild ruminants are limited, the aim of this study was (i) to assess the shedding of selected bacterial foodborne pathogens in hunted wild red deer, roe deer, chamois, and ibex, and (ii) to evaluate the microbial contamination of carcasses from hunted wild red deer, roe deer, and chamois. 


\section{Materials and methods}

\subsection{Sampling}

This study was based on investigations carried out during three months of the hunting season 2011 (September-November). Samples originated from wild red deer (Cervus elaphus), roe deer (Capreolus capreolus), chamois (Rupicapra rupicapra), and ibex (Capra ibex) hunted in the central and eastern part of Switzerland. In total, 239 fecal samples (red deer, roe deer, chamois, and ibex) and 328 carcasses (red deer, roe deer, and chamois) were examined.

Fecal samples originated from 84 red deer, 64 roe deer, 64 chamois, and 27 ibex. State gamekeepers and hunters collected the samples in the field immediately after shooting and evisceration. From each sampled animal, sex, age, and location of hunting were recorded. After opening of the large intestine, fecal matter was collected from the colon, placed into sterile tubes, and stored frozen.

In addition, carcasses from 136 red deer, 122 roe deer, and 70 chamois were sampled. Carcasses originated from six small-scale abattoirs A-F (five located in the eastern part and one located in the central part of Switzerland). Eviscerated but unskinned game animals arrived within $48 \mathrm{~h}$ after shooting at these abattoirs where they were dehided, washed (in certain abattoirs), and stored in the chiller. Carcass samples were obtained from the neck, brisket, flank, and rump area (each of $40 \mathrm{~cm}^{2}$ ) using the wet-dry double swab technique. Selected carcasses have thereby been in the chiller not longer than $72 \mathrm{~h}$. Swabs from each carcass were pooled and transported chilled.

In the laboratory, fecal samples were analyzed qualitatively for Salmonella, Listeria (L.) monocytogenes, and Escherichia (E.) coli harboring stx (Shiga toxins) and eae (intimin). Pooled carcass samples were analyzed for total viable counts (TVC) and Enterobacteriaceae.

\subsection{Salmonella spp.}

Examination for Salmonella spp. was done in accordance with ISO 6579:09.2006. From each fecal sample, $1 \mathrm{~g}$ was enriched $\left(24 \mathrm{~h}, 37^{\circ} \mathrm{C}\right)$ in $10 \mathrm{ml}$ of buffered peptone water (Oxoid AG, Pratteln, $\mathrm{CH}$ ). Three drops of the first enrichment were incubated for $48 \mathrm{~h}$ at $41.5{ }^{\circ} \mathrm{C}$ onto modified semi-solid Rappaport Vassiliadis agar (Oxoid AG). Presumptive positive samples were subcultured $\left(24 \mathrm{~h}, 37{ }^{\circ} \mathrm{C}\right)$ onto xylose-lysinedesoxycholate agar and mannitol lysine crystal violet brilliant green agar (Oxoid AG). 
Suspicious colonies were tested for biochemical properties of Salmonella.

\subsection{Listeria monocytogenes}

Examination for L. monocytogenes was done in accordance with ISO 112901:2004. From each fecal sample, $1 \mathrm{~g}$ was enriched $\left(24 \mathrm{~h}, 30^{\circ} \mathrm{C}\right)$ in $10 \mathrm{ml}$ of Fraser broth with half Fraser supplement (Oxoid AG). From the first enrichment, $0.1 \mathrm{ml}$ were incubated $\left(24 \mathrm{~h}, 37^{\circ} \mathrm{C}\right)$ in $10 \mathrm{ml}$ of Fraser broth with Fraser supplement (Oxoid AG). The second enrichment was then streaked onto chromogenic Listeria agar supplemented with Listeria selective supplement and Listeria differential supplement (Oxoid AG) and incubated for $48 \mathrm{~h}$ at $37{ }^{\circ} \mathrm{C}$. Suspicious colonies were streaked onto sheep blood agar (Difco $^{\mathrm{TM}}$ Columbia Blood Agar Base EH, Becton Dickinson AG, Allschwil, CH; 5\% sheep blood SB055, Oxoid AG) for appraisal of hemolysis (CAMP test with Staphylococcus aureus and Rhodococcus equi).

\subsection{Escherichia coli harboring stx and eae}

From each fecal sample, $1 \mathrm{~g}$ was enriched $\left(18-24 \mathrm{~h}, 37^{\circ} \mathrm{C}\right)$ in $10 \mathrm{ml}$ of modified tryptic soy broth (Oxoid AG) with $16 \mathrm{mg} / 1$ novobiocin (Sigma-Aldrich Chemie GmbH, Buchs, $\mathrm{CH}$ ). From $50 \mu \mathrm{l}$ of the enrichment broth, a lysate was made (lysis tube, Pall GeneDisc Technologies, Bruz, F). Using the commercially available closed GeneDisc ${ }^{\circledR}$ system (Pall GeneDisc Technologies), samples were screened by real-time PCR for stx and eae (Hofer et al., 2012). To compare the occurrence of stx-, eae-, or stx- and eaepositive samples among species and age groups, contingency tables (Fisher's exact test) were used.

From $s t x$-positive enrichments, subsets were streaked onto sheep blood agar and incubated for $18-24 \mathrm{~h}$ at $37{ }^{\circ} \mathrm{C}$. Five randomly selected colonies (resembling E. coli) were subcultured on sheep blood agar $\left(18-24 \mathrm{~h}, 37^{\circ} \mathrm{C}\right)$, confirmed biochemically as $E$. coli, and then tested by real-time PCR (LightCycler 2.0, Roche Diagnostics AG, Rotkreuz, $\mathrm{CH}$ ) for the presence of stx1, stx2, and eae (Hofer et al., 2012).

\subsection{Total viable counts and Enterobacteriaceae}

Pooled swabs from each carcass were homogenized in $40 \mathrm{ml}$ of $0.85 \%$ saline solution. Suspensions (and $10^{-1}$ and $10^{-2}$ dilutions) were plated with a spiral plater (Eddy Jet, IUL SA, Barcelona, E) onto plate count agar (Oxoid AG; $48-72$ h, $30^{\circ} \mathrm{C}$, aerobic 
conditions) and violet red bile glucose agar (BBL, Cockeysville, MD, USA; $48 \mathrm{~h}, 30^{\circ} \mathrm{C}$,

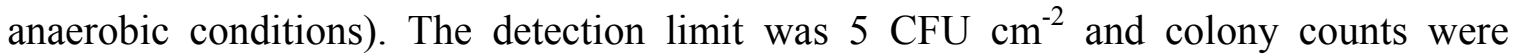

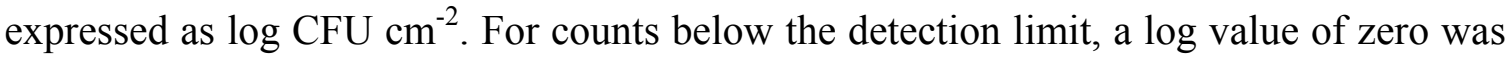
used. To analyze differences (TVC, Enterobacteriaceae counts) between animal species and abattoirs, analysis of variance and the Bonferroni procedure were performed (Stat View 4.02, Abacus Concepts Inc., Berkeley, CA, USA). To compare Enterobacteriaceae occurrence among species and abattoirs, contingency tables (Chi square test, Fisher's exact test) were used.

\section{Results}

\subsection{Salmonella spp. and Listeria monocytogenes}

All 239 fecal samples collected from hunted wild red deer $(n=84)$, roe deer $(n=64)$, chamois $(\mathrm{n}=64)$, and ibex $(\mathrm{n}=27)$ tested negative for Salmonella spp. and $L$. monocytogenes. Listeria of other species were found in $11(4.6 \%)$ fecal samples. These 11 samples originated from six $(7.1 \%)$ red deer, four $(6.3 \%)$ roe deer, and one $(1.6 \%)$ chamois.

\subsection{Escherichia coli harboring stx and eae}

Of the 239 fecal samples collected from hunted wild red deer, roe deer, chamois, and ibex, $78(32.6 \%)$ tested positive for stx only, 16 (6.7\%) for eae only, and 33 (13.8\%) for stx and eae. The proportion of stx-, eae-, and both stx- and eae-positive samples ranged from $23.4 \%$ (chamois) to $39.1 \%$ (roe deer), $3.7 \%$ (ibex) to $7.8 \%$ (roe deer and chamois), and $0 \%$ (ibex) to $21.4 \%$ (red deer), respectively (Table 1). Statistically significant differences between the animal species were only found amongst the samples that were both $s t x$ - and eae-positive $(\mathrm{P}<0.05)$. Within each species and category (st $x$-, eae-, or stx- and eae-positive), the percentage of positive samples did not statistically differ between the defined age groups (juvenile, $<1$ year of age; adult, $>1$ year of age).

Out of the 111 fecal samples in which stx genes were detected (alone or in combination with eae), 56 strains of Shiga toxin-producing E. coli (STEC) were isolated from 18 red deer, 19 roe deer, 13 chamois, and six ibex (Table 2). Twenty-five (44.6\%) strains harbored genes for only the Shiga toxin (Stx)2 group, 17 (30.4\%) for only the Stx 1 group, and $12(21.4 \%)$ for Stx1 and Stx2. With regard to the animal species, st 2 
predominated in strains from red deer, st $x 1$ or $s t x 2$ were found to an equal extent in strains from roe deer, and strains from chamois and ibex frequently harbored both stx 1 and stx2. Two of the STEC strains (positive for stx 1 or $s t x 2$ ) also harbored eae and were isolated from red deer.

\subsection{Total viable counts and Enterobacteriaceae}

To compare the carcass results from each species of wild ruminants, TVC and Enterobacteriaceae results were depicted as box plots, which allow analyzing median values, 50\% and 80\% ranges, and extreme values (Fig. 1 and 2). Mean log TVC from 136 red deer carcasses, 122 roe deer carcasses, and 70 chamois carcasses were 4.0, 4.1, and $4.2 \log$ CFU cm$~^{-2}$, respectively $(\mathrm{P}>0.05)$. Mean values from the different abattoirs ranged from 2.8-4.9 $\log \mathrm{CFU} \mathrm{cm}{ }^{-2}$ for red deer, 3.3-4.7 $\log \mathrm{CFU} \mathrm{cm} \mathrm{cm}^{-2}$ for roe deer, and 2.5-5.0 $\log$ CFU cm$~^{-2}$ for chamois (Table 3). TVC from abattoir D (red deer, chamois), abattoir F (roe deer), and partly abattoir C differed significantly from TVC of the other abattoirs $(\mathrm{P}<0.05)$.

Enterobacteriaceae were detected on carcasses from $119(87.5 \%)$ red deer, 109 $(89.3 \%)$ roe deer, and $63(90 \%)$ chamois $(\mathrm{P}>0.05)$. Mean $\log$ Enterobacteriaceae counts

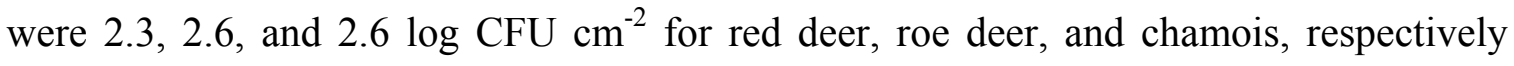
$(\mathrm{P}>0.05)$. Mean values from the different abattoirs ranged from $0.7-3.8 \log \mathrm{CFU} \mathrm{cm} \mathrm{cm}^{-2}$ for

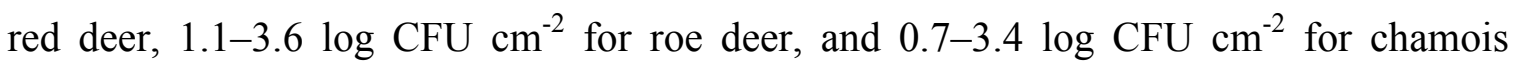
(Table 4). With regard to Enterobacteriaceae counts and prevalence, abattoir D (red deer, chamois) and abattoir F (roe deer) yielded the lowest results and differences were mainly significant $(\mathrm{P}<0.05)$.

\section{Discussion}

To assess the shedding of selected bacterial foodborne pathogens, fecal samples from 239 hunted wild red deer, roe deer, chamois, and ibex were examined for Salmonella spp., L. monocytogenes and E. coli harboring stx or eae. Salmonella are still a major cause of foodborne diseases (EFSA/ECDC, 2011), but comparable to our results Salmonella were not or only rarely detected in feces from wild ruminants (Wahlström et al., 2003; Lillehaug et al., 2005; Renter et al., 2006; Paulsen et al., 2012). Similarly, we detected no L. monocytogenes, albeit other Listeria species were occasionally found. 
However, with regard to the occurrence of Listeria on carcasses and meat, later production stages (game chambers, cold storage rooms, processing factories) must also be considered as source of contamination (Paulsen et al., 2003; Atanassova et al., 2008).

Genes for Shiga toxins and intimin were detected in a remarkable prevalence in the hunted wild ruminants. Overall, $32.6 \%$ of the fecal samples tested positive for $s t x, 6.7 \%$ for eae, and $13.8 \%$ for both stx and eae. The production of one or more Shiga toxins (Stx1, Stx2, and variants) characterizes STEC. Intimin mediates attaching and effacing lesions on intestinal epithelial cells and it is present in enteropathogenic E. coli (EPEC) and some STEC. STEC, especially the serotype O157:H7, are responsible for a number of human diseases including diarrhea, hemorrhagic colitis, and the life-threatening hemolytic-uremic syndrome (Kaper et al., 2004; Tarr et al., 2005). Human STEC infections are frequently correlated with contaminated food and deer meat has also been implicated in the transmission of STEC to humans (Keene et al., 1997; Rabatsky-Ehr et al., 2002; Ahn et al., 2009; Rounds et al., 2012). Our results suggest that wild ruminants also constitute a STEC and EPEC reservoir, a finding supported by other studies (Asakura et al., 1998; Lehmann et al., 2006; Sánchez et al., 2009; Bardiau et al., 2010; Kistler et al., 2011). Nevertheless, direct comparison of our results with the literature is hampered by varying detection procedures used. In addition, it must be mentioned that many other surveys of wild ruminants focused only on E. coli O157:H7.

STEC strains pathogenic for humans tend to feature Stx2 and other virulence traits as the adhesion factor intimin (Friedrich et al., 2002; Brooks et al., 2005). Amongst our 56 STEC strains isolated from hunted wild ruminants, st 2 was the predominant stx gene identified, especially in strains from red deer. Overall, 38 strains $(67.8 \%)$ were positive for $s t x 2$ alone or in combination with stx 1 . STEC from wild ruminants can harbor $s t x 1$ and $s t \times 2$, but $s t \times 2$ predominated in several studies (Asakura et al., 1998; Lehmann et al., 2006; Sánchez et al., 2009; Bardiau et al., 2010; Kistler et al., 2011). On the other hand, intimin genes were only detected in two (3.6\%) STEC strains from hunted wild red deer in the present study. In the few other studies not focusing on E. coli O157:H7, eae was also rarely found in STEC from wild ruminants (Lehmann et al., 2006; Sánchez et al., 2009; Bardiau et al., 2010). Hence, the risk of STEC transmission from wild ruminants to humans (via consumption of undercooked venison or other fecally contaminated foods) and to domestic ruminants (via sharing of the same pastures) must not be neglected. To 
assess the actual pathogenicity of the isolated STEC for humans, further strain characterization is required (Miko et al., 2009).

In addition, 328 dehided carcasses from hunted wild red deer, roe deer, and chamois were examined for TVC and Enterobacteriaceae by swabbing (neck, brisket, flank, rump). For the examined species of wild ruminants, mean log TVC (4.0-4.2 log CFU cm$~^{-2}$ ), mean log Enterobacteriaceae counts (2.3-2.6 $\log \mathrm{CFU} \mathrm{cm}^{-2}$ ), and Enterobacteriaceae detection rates (87.5-90\%) were at comparable levels. On the other hand, the microbial status of carcasses differed considerably between certain abattoirs. Remarkable low values were present on red deer and chamois carcasses from abattoir D and on roe deer carcasses from abattoir F. Comparability of our results with published data is hampered by differences in terms of process stages used for sample collection, carcass sampling sites, and sampling methods applied. Surveys of game (mainly red and roe deer) in Austria reported ranges of several orders of magnitude in the bacterial counts (Deutz et al., 2000; Paulsen et al., 2003; Paulsen and Winkelmayer, 2004; Deutz et al., 2006): Using swabs of the body cavity or the inside of thighs, median values ranged from 4.0-6.7 $\log \mathrm{CFU} \mathrm{cm} \mathrm{cm}^{-2}$ for TVC and 2.4-4.3 $\log \mathrm{CFU} \mathrm{cm}^{-2}$ for Enterobacteriaceae. Considerably lower counts were recently obtained in a German study investigating hunted game, including red and roe deer carcasses (Atanassova et al., 2008): Average TVC from excision samples accounted for 2.9 (red deer) and $2.6 \log \mathrm{CFU} \mathrm{cm}{ }^{-2}$ (roe deer), whereas the average Enterobacteriaceae value was $2.1 \log \mathrm{CFU} \mathrm{cm}{ }^{-2}$. The results reported by Atanassova et al. (2008) were within the legal range for carcasses from domestic ruminants (Reg. [EC] No. 2073/2005), but it must be emphasized that samples were obtained from freshly shot game under well-defined conditions. Basically, when game meat is placed on the market the same way as that from farm animals, it can be reasonable to adopt the limits specified for fresh meat from domestic ruminants (Paulsen, 2011).

In the present study (and the mentioned Austrian studies), TVC and Enterobacteriaceae values from carcasses of hunted wild ruminants were higher than those reported for slaughtered domestic ruminants (Zweifel et al., 2005; Zweifel et al., 2008). Especially Enterobacteriaceae, which are used as indicators of fecal contamination (and thereby for important bacterial pathogens), were found in remarkable frequencies and counts. This might be partly due to the difficulty to warrant a hygienically correct evisceration in the field, in particular if the shooting has lacerated the 
animal's intestines (Gill, 2007; Paulsen, 2011). In contrast to the (industrial) slaughter of domestic ruminants, the hunter eviscerates the shot animal before dehiding and often while it is lying on the ground. Hence, raising awareness of the hunters for their important role in the determination of the initial microbial contamination and its impact on the safety and quality of game is necessary. On the other hand, facilities dehiding, cooling and processing carcasses from wild ruminants must be aware of the associated challenges in order to avoid contaminations.

Consequently, strict compliance with good hunting and hygiene practices during any step from shooting, through evisceration in the field, to dehiding and processing is of central importance to avoid contaminations and to prevent foodborne pathogens carried by the animals (in their intestines or hides) from entering the food chain. Such measures ensure both public health protection and meat quality. The low microbial results observed on carcasses from certain abattoirs show that carcasses from hunted wild ruminants can be of a good hygienic status.

\section{References}

Ahn, C.K., Russo, A.J., Howell, K.R., Holt, N.J., Sellenriek, P.L., Rothbaum, R.J., Beck, A.M., Luebbering, L.J., Tarr, P.I., 2009. Deer sausage: A newly identified vehicle of transmission of Escherichia coli O157:H7. J. Pediatr. 155, 587-589.

Asakura, H., Makino, S., Shirahata, T., Tsukamoto, T., Kurazono, H., Ikeda, T., Takeshi, K., 1998. Detection and genetical characterization of Shiga toxin-producing Escherichia coli from wild deer. Microbiol. Immunol. 42, 815-822.

Atanassova, V., Apelt, J., Reich, F., Klein, G., 2008. Microbiological quality of freshly shot game in Germany. Meat Sci. 78, 414-419.

BAFU, Bundesamt für Umwelt, 2010. Eidgenössische Jagdstatistik. http://www.wild.uzh.ch/jagdst (Accessed 27 January 2012).

Bardiau, M., Grégoire, F., Muylaert, A., Nahayo, A., Duprez, J.-N., Mainil, J., Linden, A., 2010. Enteropathogenic (EPEC), enterohaemorragic (EHEC) and verotoxigenic (VTEC) Escherichia coli in wild cervids. J. Appl. Microbiol. 109, 2214-2222.

Brooks, J.T., Sowers, E.G., Wells, J.G., Greene, K.D., Griffin, P.M., Hoekstra, R.M., Strockbine, N.A., 2005. Non-O157 Shiga toxin-producing Escherichia coli infections in the United States, 1983-2002. J. Infect. Dis. 192, 1422-1429.

Deutz, A., Fuchs, K., Pless, P., Deutz-Pieber, U., Köfer, J., 2000. Hygienerisiken bei Wildfleisch Oberflächenkeimgehalte und humanpathogene Keime. Fleischwirtsch. 80 (12), 106-108. 
Deutz, A., Völk, F., Pless, P., Fötschl, H., Wagner, P., 2006. Wildfleischhygienische Aspekte zu Stöberjagden auf Rot- und Rehwild. Arch. Lebensmittelhyg. 57, 197-202.

EFSA/ECDC, European Food Safety Authority/European Center for Disease Prevention and Control, 2011. The European Union summary report on trends and sources of zoonoses, zoonotic agents and foodborne outbreaks in 2009. EFSA Journal 2090.

Friedrich, A.W., Bielaszewska, M., Zhang, W.-L., Pulz, M., Kuczius, T., Ammon, A., Karch, H., 2002. Escherichia coli harboring Shiga toxin 2 gene variants: Frequency and association with clinical symptoms. J. Infect. Dis. 185, 74-84.

Gill, C.O., 2007. Microbiological conditions of meats from large game animals and birds. Meat Sci. 77, 149-160.

Hofer, E., Stephan, R., Reist, M., Zweifel, C., 2012. Application of a real-time PCR-based system for monitoring of O26, O103, O111, O145, and O157 Shiga toxin-producing Escherichia coli in cattle at slaughter. Zoonoses Public Health, in press.

Kaper, J.B., Nataro, J.P., Mobley, H.L.T., 2004. Pathogenic Escherichia coli. Nat. Rev. Microbiol. 2, 123140.

Keene, W.E., Sazie, E., Kok, J., Rice, D.H., Hancock, D.D., Balan, V.K., Zhao, T., Doyle, M.P., 1997. An outbreak of Escherichia coli O157:H7 infections traced to jerky made from deer meat. JAMA - J. Am. Med. Assoc. 277, 1229-1231.

Kistler, W.M., Mulugeta, S., Mauro, S.A., 2011. Detection of $s t x_{1}$ and $s t x_{2}$ genes in Pennsylvanian whitetailed deer. Toxins 3, 640-646.

Lehmann, S., Timm, M., Steinrück, H., Gallien, P., 2006. Nachweis von STEC im Kot von Hochwild und in Wildfleischproben. Fleischwirtsch. 86 (4), 93-96.

Lillehaug, A., Bergsjø, B., Schau, J., Bruheim, T., Vikøren, T., Handeland, K., 2005. Campylobacter spp., Salmonella spp., verocytotoxic Escherichia coli, and antibiotic resistance in indicator organisms in wild cervids. Acta Vet. Scand. 46, 23-32.

Membré, J.-M., Laroche, M., Magras, C., 2011. Assessment of levels of bacterial contamination of large wild game meat in Europe. Food Microbiol. 28, 1072-1079.

Miko, A., Pries, K., Haby, S., Steege, K., Albrecht, N., Krause, G., Beutin, L., 2009. Assessment of Shiga toxin-producing Escherichia coli isolates from wildlife meat as potential pathogens for humans. Appl. Environ. Microbiol. 75, 6462-6470.

Nørrung, B., Buncic, S., 2008. Microbial safety of meat in the European Union. Meat Sci. 78, 14-24.

Paulsen, P., 2011. Hygiene and microbiology of meat from wild game: An Austrian view. In: Paulsen, P., Bauer, A., Vodnansky, M., Winkelmayer, R., Smulders, F.J.M. (Eds.), Game meat hygiene in focus: Microbiology, epidemiology, risk analysis and quality assurance, Wageningen Academic Publishers, Wageningen, pp. 19-37.

Paulsen, P., Hilbert, F., Winkelmayer, R., Mayrhofer, S., Hofbauer, P., Smulders, F.J.M., 2003. Zur tierärztlichen Fleischuntersuchung von Wild, dargestellt an der Untersuchung von Rehen in Wildfleischbearbeitungsbetrieben. Arch. Lebensmittelhyg. 54, 137-140.

Paulsen, P., Smulders, F.J.M., Hilbert, F., 2012. Salmonella in meat from hunted game: A central Europe perspective. Food Res. Int., in press, doi: 10.1016/j.foodres.2011.06.055. 
Paulsen, P., Winkelmayer, R., 2004. Seasonal variation in the microbial contamination of game carcasses in an Austrian hunting area. Eur. J. Wildl. Res. 50, 157-159.

Proviande, 2010. $\quad$ Der $\quad$ Fleischmarkt im Überblick 2010. http://www.schweizerfleisch.ch/nc/proviande/statistik.html (Accessed 27 January 2012).

Rabatsky-Ehr, T., Dingman, D., Marcus, R., Howard, R., Kinney, A., Mshar, P., 2002. Deer meat as the source for a sporadic case of Escherichia coli O157:H7 infection, Connecticut. Emerg. Infect. Dis. $8,525-527$.

Renter, D.G., Gnad, D.P., Sargeant, J.M., Scott, E., Hygnstrom, S.E., 2006. Prevalence and serovars of Salmonella in the feces of free-ranging white-tailed deer (Odocoileus virginianus) in Nebraska. J. Wildl. Dis. 42, 699-703.

Rounds, J.M., Rigdon, C.E., Muhl, L.J., Forstner, M., Danzeisen, G.T., Koziol, B.S., Taylor, C., Shaw, B.T., Short, G.L., Smith, K.E., 2012. Non-O157 Shiga toxin-producing Escherichia coli associated with venison. Emerg. Infect. Dis. 18, 279-282.

Sánchez, S., García-Sánchez, A., Martínez, R., Blanco, J., Blanco, J.E., Blanco, M., Dahbi, G., Mora, A., Hermoso de Mendoza, J., Alonso, J.M., Rey, J., 2009. Detection and characterization of Shiga toxinproducing Escherichia coli other than Escherichia coli O157:H7 in wild ruminants. Vet. J. 180, 384388.

Tarr, P., Gordon, C.A., Chandler, W.L., 2005. Shiga toxin-producing Escherichia coli and haemolytic uraemic syndrome. Lancet 365, 1073-1086.

Wahlström, H., Tysén, E., Olsson Engvall, E., Brändström, B., Eriksson, E., Mörner, T., Vågsholm, I., 2003. Survey of Campylobacter species, VTEC O157 and Salmonella species in Swedish wildlife. Vet. Rec. 153, 74-80.

Zweifel, C., Baltzer, D., Stephan, R., 2005. Microbiological contamination of cattle and pig carcasses at five abattoirs determined by swab sampling in accordance with EU Decision 2001/471/EC. Meat Sci. 69, 559-566.

Zweifel, C., Fischer, R., Stephan, R., 2008. Microbiological contamination of pig and cattle carcasses in different small-scale Swiss abattoirs. Meat Sci. 78, 225-231. 


\section{Tables}

\section{Table 1}

Detection of stx and eae genes in fecal samples obtained from hunted wild red deer, roe deer, chamois, and ibex (juvenile, $<1$ year of age; adult, $>1$ year of age).

\begin{tabular}{|c|c|c|c|c|c|c|}
\hline $\begin{array}{l}\text { Origin/ } \\
\text { Age group }\end{array}$ & $\begin{array}{c}\text { No. of } \\
\text { samples }\end{array}$ & & $s t x^{+}$ & $e a e^{+}$ & $s t x^{+}$ & and eae ${ }^{+}$ \\
\hline Red deer & 84 & 31 & (36.9\%) & $5(6.0 \%)$ & 18 & (21.4\%) \\
\hline Juvenile & 22 & 10 & $(45.5 \%)$ & $0 \quad(0.0 \%)$ & 5 & $(22.7 \%)$ \\
\hline Adult & 62 & 21 & $(33.9 \%)$ & $5 \quad(8.1 \%)$ & 13 & $(21.0 \%)$ \\
\hline Roe deer & 64 & 25 & (39.1\%) & $5 \quad(7.8 \%)$ & 12 & (18.8\%) \\
\hline Juvenile & 24 & 11 & $(45.8 \%)$ & $1 \quad(4.2 \%)$ & 3 & $(12.5 \%)$ \\
\hline Adult & 40 & 14 & $(35.0 \%)$ & $4(10.0 \%)$ & 9 & $(22.5 \%)$ \\
\hline Chamois & 64 & 15 & (23.4\%) & $5 \quad(7.8 \%)$ & 3 & $(4.7 \%)$ \\
\hline Juvenile & 9 & 2 & $(22.2 \%)$ & $2(22.2 \%)$ & 0 & $(0.0 \%)$ \\
\hline Adult & 55 & 13 & $(23.6 \%)$ & $3(5.5 \%)$ & 3 & $(5.5 \%)$ \\
\hline Ibex (adult) & 27 & 7 & $(25.9 \%)$ & $1(3.7 \%)$ & $\mathbf{0}$ & $(0.0 \%)$ \\
\hline Total & 239 & 78 & (32.6\%) & $16(6.7 \%)$ & 33 & (13.8\%) \\
\hline
\end{tabular}




\section{Table 2}

Detection of stx 1 , st 2 , and eae genes amongst 56 strains of Shiga toxin-producing Escherichia coli isolated from fecal samples of hunted wild red deer $(\mathrm{n}=18)$, roe deer $(n=19)$, chamois $(n=13)$, and ibex $(n=6)$.

\begin{tabular}{lcccc}
\hline Origin & $\begin{array}{c}\text { No. of } \\
\text { strains }\end{array}$ & stx 1 & stx2 & eae \\
\hline \multirow{2}{*}{ Red deer } & 13 & - & + & - \\
& 2 & + & - & - \\
& 1 & + & + & - \\
& 1 & + & - & + \\
Roe deer & 1 & - & + & + \\
& 9 & + & - & - \\
Chamois & 9 & - & + & - \\
& 1 & + & + & - \\
Ibex & 7 & + & + & - \\
& 4 & + & - & - \\
& 2 & - & + & - \\
& 3 & + & + & - \\
& 2 & + & - & - \\
\hline
\end{tabular}




\section{Table 3}

TVC results ( $\log \mathrm{CFU} \mathrm{\textrm {cm } ^ { - 2 }}$ ) on carcasses obtained from hunted wild red deer, roe deer, and chamois at six small-scale abattoirs.

\begin{tabular}{|c|c|c|c|c|c|c|c|c|c|}
\hline \multirow{2}{*}{$\begin{array}{l}\text { Abattoir (total No of } \\
\text { sampled carcasses) }\end{array}$} & \multicolumn{3}{|c|}{ Red deer carcasses ${ }^{\mathrm{a}}$} & \multicolumn{3}{|c|}{ Roe deer carcasses } & \multicolumn{3}{|c|}{ Chamois carcasses } \\
\hline & $\mathrm{n}$ & $\overline{\mathrm{x}}$ & S.D. & $\mathrm{n}$ & $\overline{\mathrm{x}}$ & S.D. & $\mathrm{n}$ & $\bar{x}$ & S.D. \\
\hline Abattoir A $(n=121)$ & 63 & 3.95 & 0.62 & 33 & 4.52 & 0.69 & 25 & 4.32 & 0.89 \\
\hline Abattoir B $(n=102)$ & 44 & 3.88 & 0.84 & 36 & 4.09 & 0.82 & 22 & 3.90 & 0.53 \\
\hline Abattoir $C \quad(n=53)$ & 19 & 4.90 & 0.95 & 18 & 4.72 & 0.70 & 16 & 4.96 & 0.59 \\
\hline Abattoir D $\quad(n=14)$ & 8 & 2.81 & 0.68 & 1 & 3.48 & nd & 5 & 2.51 & 1.61 \\
\hline Abattoir E $\quad(n=11)$ & 2 & 4.79 & 0.20 & 7 & 4.13 & 0.74 & 2 & 4.63 & 0.64 \\
\hline Abattoir F $\quad(n=27)$ & $\mathrm{na}^{\mathrm{b}}$ & $\mathrm{nd}^{\mathrm{c}}$ & nd & 27 & 3.30 & 0.63 & na & nd & nd \\
\hline$(n=328)$ & 136 & 4.01 & 0.87 & 122 & 4.12 & 0.87 & 70 & 4.22 & 0.99 \\
\hline
\end{tabular}

${ }^{a}$ n: No of samples; $\bar{x}$ : mean $\log C F U \mathrm{~cm}^{-2}$; S.D.: standard deviation.

${ }^{\mathrm{b}}$ na: not available; ${ }^{\mathrm{c}}$ nd: no data for calculation. 


\section{Table 4}

Enterobacteriaceae results $\left(\log \mathrm{CFU} \mathrm{cm} \mathrm{cm}^{-2}\right)$ on carcasses obtained from hunted wild red deer, roe deer, and chamois at six small-scale abattoirs.

\begin{tabular}{|c|c|c|c|c|c|c|c|c|c|}
\hline \multirow{2}{*}{$\begin{array}{l}\text { Abattoir (total No of } \\
\text { sampled carcasses) }\end{array}$} & \multicolumn{3}{|c|}{ Red deer carcasses ${ }^{a}$} & \multicolumn{3}{|c|}{ Roe deer carcasses } & \multicolumn{3}{|c|}{ Chamois carcasses } \\
\hline & $\mathrm{n}$ & $\overline{\mathrm{x}}$ & S.D. & $\mathrm{n}$ & $\overline{\mathrm{x}}$ & S.D. & $\mathrm{n}$ & $\overline{\mathrm{x}}$ & S.D. \\
\hline Abattoir A $(n=121)$ & 63 & 2.14 & 1.06 & 33 & 3.20 & & 25 & 2.93 & 0.95 \\
\hline Abattoir B $(n=102)$ & 44 & 2.12 & 1.36 & 36 & 2.60 & 1.19 & 22 & 2.06 & 1.14 \\
\hline Abattoir $\mathrm{C} \quad(\mathrm{n}=53)$ & 19 & 3.82 & 1.33 & 18 & 3.63 & & 16 & 3.42 & 0.96 \\
\hline Abattoir D $\quad(n=14)$ & 8 & 0.73 & 1.02 & 1 & 3.06 & nd & 5 & 0.68 & 1.53 \\
\hline Abattoir E $\quad(n=11)$ & 2 & 3.18 & 0.08 & 7 & 2.98 & 1.50 & 2 & 3.36 & 1.16 \\
\hline Abattoir F $\quad(n=27)$ & $\mathrm{na}^{\mathrm{b}}$ & $\mathrm{nd}^{\mathrm{c}}$ & nd & 27 & 1.08 & 1.12 & na & nd & nd \\
\hline$(n=328)$ & 136 & 2.30 & 1.38 & 122 & 2.60 & 1.40 & 70 & 2.62 & 1.28 \\
\hline
\end{tabular}

${ }^{a}$ n: No of samples; $\bar{x}$ : mean $\log C F U \mathrm{~cm}^{-2}$; S.D.: standard deviation.

${ }^{\mathrm{b}}$ na: not available; ${ }^{\mathrm{c}}$ nd: no data for calculation. 


\section{Figures}

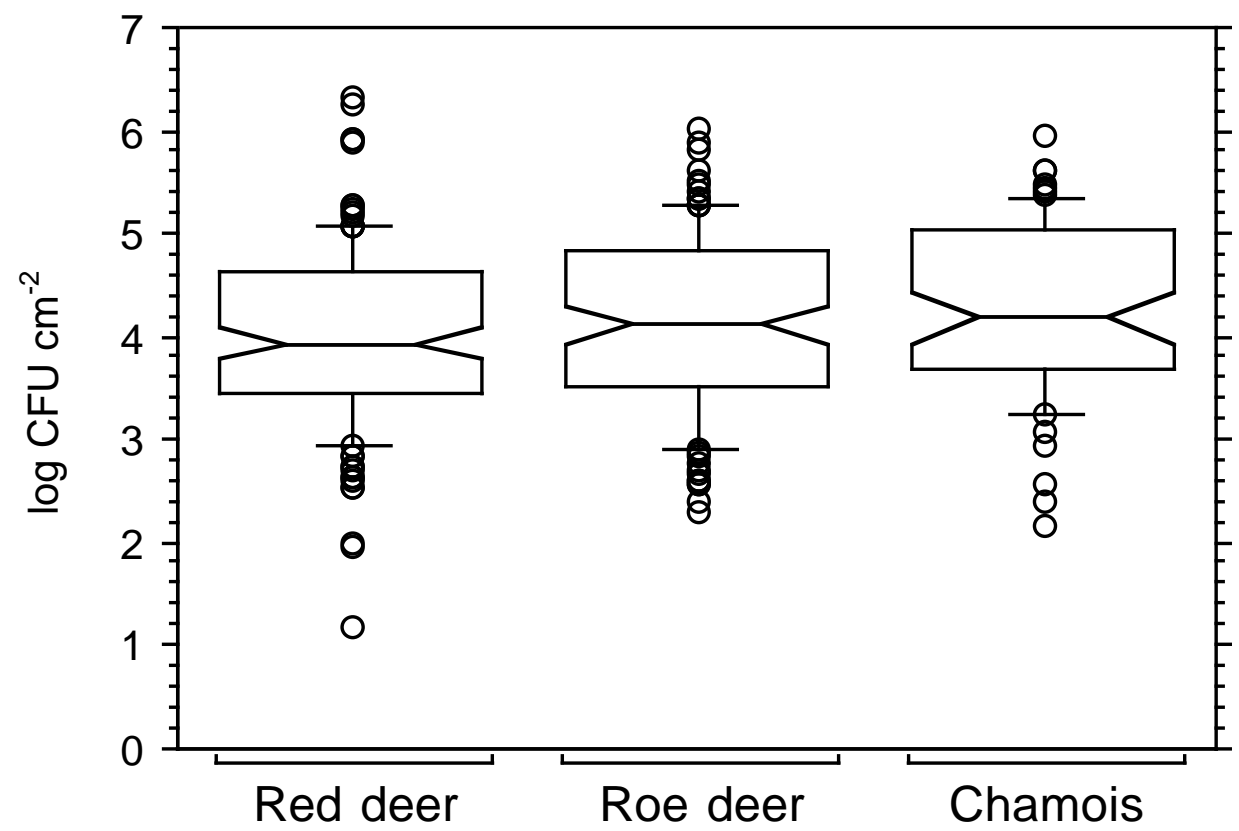

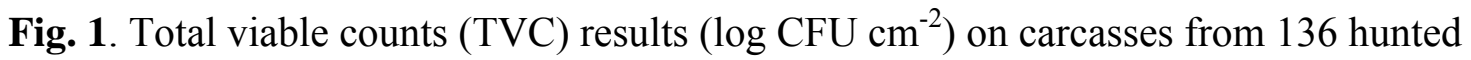
wild red deer, 122 hunted wild roe deer, and 70 hunted wild chamois. 


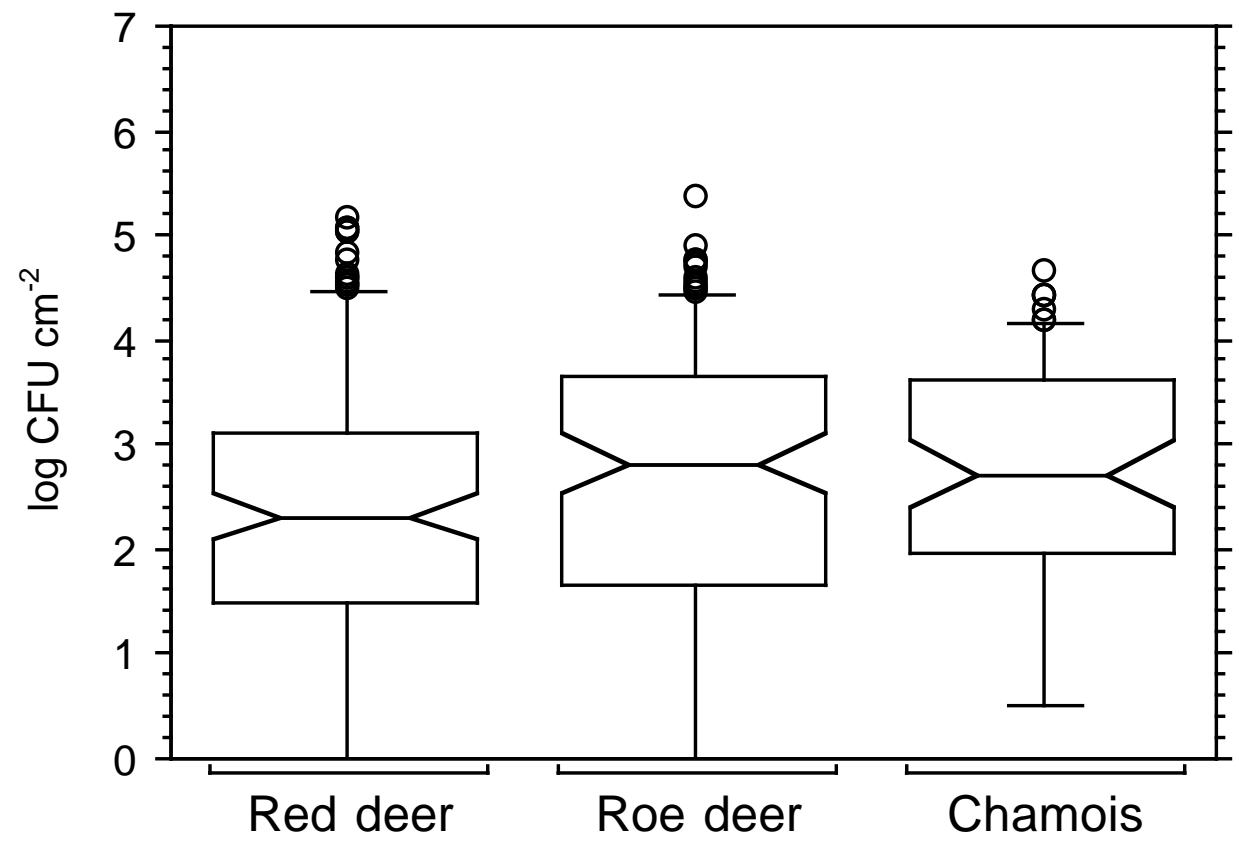

Fig. 2. Enterobacteriaceae results $\left(\log \mathrm{CFU} \mathrm{cm} \mathrm{cm}^{-2}\right)$ on carcasses from 136 hunted wild red deer, 122 hunted wild roe deer, and 70 hunted wild chamois. 


\section{Acknowledgements}

I would like to express my gratitude to all those who contributed to this work: the state gamekeepers and hunters for the collection of the fecal samples from hunted wild ruminants and the staff of the slaughterhouses for facilitating access to their operations. This project was partially funded by the Swiss Army.

Special thanks go to:

Prof. Roger Stephan, Institute for Food Safety and Hygiene, Vetsuisse Faculty University of Zürich, for giving me the opportunity to work on this scientific project, for his optimistic support and help when ever needed.

PD Dr. Claudio Zweifel, Institute for Food Safety and Hygiene, Vetsuisse Faculty University of Zürich, for his patience, for his help whenever necessary and for the preparation of the main review.

The whole ILS Team for their assistance and creation of a friendly working atmosphere.

All the other $\mathrm{PhD}$ and doctoral thesis students for the good times.

My family for their care and appreciation. 


\section{Curriculum Vitae}

Name

Geburtsdatum

Geburtsort

Nationalität

Heimatort

$8 / 1991-7 / 2000$

$8 / 2000-7 / 2004$

$26 / 8 / 2004$

9/2005-9/2010

$22 / 9 / 2010$

$8 / 2011-2 / 2012$
Tobias, Obwegeser

3. Januar 1985

Grabs SG

Schweizer

Schwerzenbach ZH

Primar- und Sekundarschule, Gams, Schweiz

Kantonsschule, Sargans, Schweiz

Erlangung der Maturität an der Kantonsschule Sargans,

Schwerpunkt Biologie und Chemie

Studium der Veterinärmedizin an der Vetsuisse-Fakultät

Universität Bern, Schweiz

Erlangung des Diploms für Tierärzte an der Vetsuisse-Fakultät

Universität Bern, Schweiz

Anfertigung der Dissertation

unter der Leitung von Prof. Dr. Roger Stephan

am Institut für Lebensmittelsicherheit und -hygiene

der Vetsuisse-Fakultät, Universität Zürich, Schweiz 